\title{
An exploration of in-service teachers' understanding of teaching mathematics in Grade $R$ classrooms: A case study of Grade $R$ in Lesotho University of KwaZulu-Natal, South Africa
}

\begin{tabular}{|c|c|}
\hline \multicolumn{2}{|c|}{$\begin{array}{l}\text { Authors: } \\
\text { Mamasiphole Setoromo }{ }^{1} \text { ( } \\
\text { Blanche Hadebe-Ndlovu }\end{array}$} \\
\hline \multicolumn{2}{|c|}{$\begin{array}{l}\text { Affiliations: } \\
{ }^{1} \text { School of Education, } \\
\text { University of KwaZulu-Natal, } \\
\text { Durban, South Africa }\end{array}$} \\
\hline \multicolumn{2}{|c|}{$\begin{array}{l}\text { Corresponding author: } \\
\text { Blanche Hadebe-Ndlovu, } \\
\text { ndlovubl@ukzn.ac.za }\end{array}$} \\
\hline \multicolumn{2}{|c|}{$\begin{array}{l}\text { Dates: } \\
\text { Received: } 08 \text { Aug. } 2016 \\
\text { Accepted: } 05 \text { Mar. } 2020 \\
\text { Published: } 23 \text { July } 2020\end{array}$} \\
\hline \multicolumn{2}{|c|}{$\begin{array}{l}\text { How to cite this article: } \\
\text { Setoromo, M. \& } \\
\text { Hadebe-Ndlovu, B., 2020, } \\
\text { 'An exploration of in-service } \\
\text { teachers' understanding of } \\
\text { teaching mathematics in } \\
\text { Grade R classrooms: A case } \\
\text { study of Grade R in Lesotho } \\
\text { University of KwaZulu-Natal, } \\
\text { South Africa', South African } \\
\text { Journal of Childhood } \\
\text { Education 10(1), a487. } \\
\text { https://doi.org/10.4102/ } \\
\text { sajce.v10i1.487 }\end{array}$} \\
\hline \multicolumn{2}{|c|}{$\begin{array}{l}\text { Copyright: } \\
\text { (c) 2020. The Authors. } \\
\text { Licensee: AOSIS. This wo } \\
\text { is licensed under the } \\
\text { Creative Commons } \\
\text { Attribution License. }\end{array}$} \\
\hline \multicolumn{2}{|l|}{ Read online: } \\
\hline 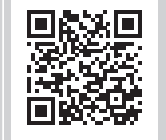 & $\begin{array}{l}\text { Scan this QR } \\
\text { code with your } \\
\text { smart phone or } \\
\text { mobile device } \\
\text { to read online. }\end{array}$ \\
\hline
\end{tabular}

Background: Research has indicated that young learners are capable of learning mathematics because they are born with an innate core of mathematics knowledge. Teachers of young learners are, therefore, expected to offer mathematical curriculum that exposes learners to a deep and explicit knowledge of high mathematics.

Aim: The study aimed at Grade R in-service teachers' understanding of teaching mathematics in their classrooms.

Setting: The study sampled five in-service Grade R teachers from four districts in Lesotho, while they were enrolled in an in-service programme at a college of Education.

Methods: This is a qualitative approach, and a case study design was employed. Data sources included teachers' interviews, classroom observations and document analysis for instance, the teachers' files, lesson plans for Grade R curriculum for mathematics and course outline of mathematics offered to in-service teachers during their training in the Lesotho College of Education (LCE). Which focussed on four domains of knowledge, namely, common content knowledge, special content knowledge, knowledge of content and students, and knowledge of content and teaching.

Results: The findings revealed that the in-service teachers in the LCE had insufficient understanding of the teaching of mathematics, which in turn had a negative influence on the teaching of mathematics in Grade R classes.

Conclusion: Despite the Lesotho government's commitment to improving the learning of mathematics at the Grade $\mathrm{R}$ level. Teachers' difficulties raise concerns about the effectiveness of their teaching of mathematics.

Keywords: classroom; Grade R; in-service teachers; mathematics; teaching; learners.

\section{Introduction}

In Lesotho, Early Childhood Education started as a project supported by Bernard Van Leer and the United Nations International Children Emergency Fund (UNICEF) way back in the 1970s when women's associations still took care of the children in their communities. It became a priority after the declaration of the first Millennium Development Goals (MDGs), and the slogan 'Education for All' became popular. This slogan expresses the paramount importance of Early Childhood Care and Development (ECCD) and therefore calls on governments to expand and improve a comprehensive Early Childhood Care and Education (ECCE) system, especially for the most vulnerable and disadvantaged children in their societies.

It is against this background that the government of Lesotho, through the Ministry of Education and Training (MoET 2005), established the Intergraded Early Childhood Care and Development (IECCD) unit in 1995. This unit became part of the mainstream in the MoET. The IECCD unit has its own mandates to fulfil, namely, to expand and promote early childhood programmes countrywide, to coordinate and supervise provision of services at the ministerial level, to provide equitable access to IECCD facilities, to improve the quality of IECCD programmes and to mainstream all children into the IECCD programme, regardless of their human immunodeficiency virus / acquired immune deficiency syndrome status and their gender during the early years (Williams 2008; Department of Education and Early Childhood Development 2011). 
The Education Statistics Bulletin (Lesotho Ministry of Education and Training 2012) reported that the Lesotho education system is structured into different levels, with learners spending a designated number of years in each level before they qualify to proceed to the next level. Hence, this article intends to evaluate how in-service teachers' training influences their understanding of the teaching of mathematics in Grade R.

The first level of education in Lesotho consists of 7 years of primary school education, at the end of which learners are awarded the Primary School Leaving Certificate (PSLC). From 2007, this level was allocated an additional time period during which learners, aged between 4 and 5 years, spend 1 year in Reception class (Grade R) before they are enrolled in Grade 1. This article focusses on the Grade $\mathrm{R}$ year and explores how in-service teachers understood the teaching of mathematics in this particular phase of primary school education.

After the 'Education for All' approach had been launched by the MDGs declaration, a second approach was introduced, which is called the Reception class, which caters for Grade $\mathrm{R}$ learners. This approach was established to fast track the implementation of the MDGs in response to the call for 'Education for All'. The Lesotho government, through the MoET, prioritised early childhood education (ECE) and, in 2007, embarked on the process of attaching Grade R classes to government, community and church-registered primary schools. Currently, there are 220 Grade R classes in the entire country with attachments of 32 classes in the district of Maseru, 25 classes in Berea and 25 classes in Mohale's Hoek (Educational Statistics Bulletin 2012). The schools that served as the research sites for this study are located in the abovementioned districts.

With the Grade R approach, 5-year-old learners are enrolled. Because primary school education is free in Lesotho, Grade $\mathrm{R}$ classes are also free, and parents do not pay school fees or for meals that are provided through a school feeding programme. The main purposes of Grade R in Lesotho are (1) to prepare learners for a smooth transition to Grade 1 when they turn 6 years of age and (2) to increase access to and expand ECE in the country in order to reach every Mosotho child (Education Sector Strategic Plan for 2005-2015).

However, now that ECE has been formalised in Lesotho, there is some concern regarding the quality of education provided by caregivers to learners in Grade R. As a result, the Lesotho government, through the Ministry of Education, requested the Lesotho College of Education (LCE), where teachers are trained, to launch a 2-year in-service training programme at the college. This programme aims at training and capacitating all caregivers working at the various ECE centres, with preference to those who teach in Grade $\mathrm{R}$ classes. In 2007, a Certificate in Early Childhood Education (CECE) was established, and the first intake was in June 2007. Since then, admissions have been undertaken every year in this programme (Educational Statistics Bulletin 2012).

\section{The research objectives}

This research intended to achieve the following objectives:

- to evaluate in-service teachers' understanding of the teaching of mathematics in Grade $R$

- to examine how in-service teachers' understanding of the teaching of mathematics influences their teaching of mathematics in Grade R.

\section{Critical research questions}

This research was guided by the following research questions:

- What is the understanding of in-service teachers of the teaching of mathematics in Grade R?

- How does in-service teachers' understanding of the teaching of mathematics influence their teaching of mathematics in Grade R?

\section{Literature review}

According to Kiggundu (2007) and Nancy (2007), the research on preservice teachers' development that provides them with practice allows and helps them to focus on learning in and from practice that includes prospects for observation of learners' thinking skills. Mathematics preservice teachers need to be allowed to participate in teacher study groups (Stigler \& Hiebert 1999). This will allow them to reflect on teaching practices (Schifter 1996; UNICEF 1994) and develop critical thinking in discussing teaching circumstances (Barnett \& Tyson 1999). This means that teachers of young learners are advised to know mathematical content, to use appropriate pedagogical content knowledge (PCK) and to motivate learners through games and activities.

However, De Lemos and Doig (1999) argued that the introduction of numeracy concepts through play pedagogies does not capacitate learners with numeracy skills. The play pedagogies do not allow learners to achieve high levels of mathematics. Lampert and Ball (1998) confirmed that the overall teacher education had weak interventions on the powerful images, understandings and beliefs, and thinking that teachers are expected to convey in the classrooms. The National Association for the Education of Young Children (NAEYC) and the National Council of Teachers (NCTM) (2002) suggested that teaching that promotes problem solving, reasoning and many other mathematical concepts is consistent with the national reports on mathematics education. This knowledge will also assist teachers in knowing the purpose of teaching mathematics to young learners. The NCTM of mathematics and the NAEYC also affirm that it is significant that teachers use challenging approaches for young learners to understand mathematics.

Benner and Hatch (2009) stated that teachers of young learners have a critical role to play in improving the academic mathematics results of learners; as a result, there is a need to be capacitated so that they are competent to teach mathematics. Jung and Conderman (2013) emphasised that 
ongoing professional training will assist teachers in improving their teaching and in engaging in intentional teaching of mathematics. Moreover, it encourages learners to learn independently and therefore teachers are required to be creative and purposeful in all aspects of teaching mathematics in Grade R. For instance, they should plan lessons with learning objectives, employ effective teaching strategies to help learners achieve the set objectives, interact with learners, assess their progress and modify mathematics lessons based on assessment results. Walia (2012) argued that with the Chinese, traditional approaches are said to be teacher-centred, therefore allowing them to impart correct knowledge to learners. Borg (2011) stated that direct knowledge transmission is what is expected of teachers in the early years to allow learners more information in mathematics teaching. Aubrey (1997) supported such endeavours where it is stated that it is the teachers' fundamental duty to assist learners to learn.

\section{Major content areas of mathematics for Grade R}

The awareness of and the need to teach mathematics to Grade $\mathrm{R}$ learners captured the attention of various researchers, who then embarked on conducting different studies focussing on various major content areas of mathematics that Grade $R$ learners need to learn and master. Numbers and operations seem to have attracted many researchers such as McGuire, Kinzie and Berch (2011), who published a paper on developing number sense in Pre-K with Five-Frames. Jordan, Kaplan and Locuniak (2009) published a paper that explored learners' number competence and later mathematical skills. They concluded that it is important for learners in Grade $\mathrm{R}$ to develop number competence because it forms a good basis for their development in elementary school mathematics, as being competent in numbers and operations forms a solid foundation for the learning of other domains of mathematics. Moreover, Van de Rijt Van Luit and Pennings (1999) outlined that there are different mathematical concepts involved in counting situations such as cardinal counting and situations that relate to the sequence of cardinal numbers, measurement, ordinal situations, symbolic situations and non-numerical situations that contribute to the development of counting for learners. As a result, they also form a solid foundation for the later learning of mathematical skills. This validates the point that Grade $\mathrm{R}$ learners should therefore be exposed to all number situations so that a solid foundation for mathematics is laid.

The Community Learner Care of Victoria (2011:8) stated that classroom activities should involve mathematical concepts that lead to 'numerical reasoning, classifying, grouping, sorting, recognising, distinguishing, symbolising and representing'. Missall et al. (2012) indicated that learners develop mathematics concurrently across five major content areas of mathematics, namely, numbers and operations, geometry, algebra, measurement and data analysis. These major content areas of mathematics exist and are further cultivated as learners grow but occur at different levels of sophistication. Greenes, Ginsburg and Balfanz (2004) pointed out that teachers should avoid limiting major content areas of mathematics to counting, shape identification, the identification and completion of repeating patterns and an introduction to measurement comparisons. This suggests that teachers should teach all major content areas of mathematics as stipulated in the curriculum. However, they should not only introduce mathematical concepts and skills but also expose learners to explicit mathematical knowledge by maintaining and enriching mathematical ideas in a playful manner through a variety of activities.

Notably, Missall et al. (2012) contextualised mathematics for Grade $\mathrm{R}$ by explaining it as follows:

\begin{abstract}
... [N]umbers and numbers operations encompass the skills of number knowledge, verbal counting, basic calculation and quantity comparisons; geometry is defined by identifying shapes and describing spatial relations; measurement skills include identifying quantifiable attributes and comparing objects using the attributes; algebra translates to skills related to identifying patterns and bringing organisation and predictability to unorganised situations; and data analysis concerns classifying and ordering information to ask and answer questions. (p. 96)
\end{abstract}

Missall et al. (2012) concluded that the mathematical skills detailed above indicate the basis upon which further education and real-life functioning are grounded.

\section{Psychological perspectives on the way learners learn mathematics}

This section reviews literature on how different theorists view the learning of mathematics by young learners. The review focusses on the psychological point of view of three theorists, namely, Piaget, Vygotsky and Bruner, and explores the constructivism philosophy of learning.

\section{Factors that contribute to the effective learning of mathematics in Grade R}

\section{Learning environment}

It is stated that learners in the preoperational stage learn by manipulating concrete materials; hence, during the teaching and learning of mathematics, teachers need to create a classroom environment that will enable learners to manipulate concrete materials (Varol \& Farran 2006). This process will enable learners to have unlimited access to challenging mathematics learning (Varol \& Farran 2006). This means that teachers should provide a favourable learning (i.e. classroom) environment that motivates learners to learn mathematics spontaneously. For instance, Ginsburg, Lee and Boyd (2008) stated that physical classroom environments differ in terms of quality. Where the existing physical classroom environment is unattractive and unappealing, it needs to be improved, because a classroom environment that is conducive for the learning of mathematics is one that has a variety of objects and materials that enrich and arouse learners' curiosity to learn 
mathematics. In the case of Grade R, such materials could be blocks, puzzles and a fantasy area. Clement (2001) added that although high-quality learning in Grade $\mathrm{R}$ is sometimes incidental or informal, it still has to be planned and prepared for all the time. This suggests that teachers are expected to organise the learning environment in a manner that creates opportunities for learners to explore mathematical concepts. The class environment could include, for example, unit blocks and a 'shopping centre', as these will expose learners to a variety of mathematical concepts while they play.

Varol and Farran (2006) suggested that the classroom should have external and internal characteristics. By external characteristics, they mean things like the arrangement of the furniture in the classroom and the additional materials and their display to arouse learners' interest and maintain learners' acceptable social behaviour. By internal characteristics, they refer to the internal characteristics of teachers, which are their personal qualities such as their attitudes and beliefs regarding mathematics, and learners' attitude to and knowledge of mathematics. Varol and Farran (2006) indicated that these characteristics are essential because they are capable of transforming a classroom into a learning environment that advances learners' ability to learn mathematics. However, Ginsburg et al. (2008) pointed out that teachers should be aware that a rich environment alone does not guarantee effective learning of mathematics; the most important thing is what learners are doing in that classroom. Therefore, teachers should provide the necessary support to all learners so that they learn mathematics effectively. International Step by Step Association (ISSA 2010) added that the learning environment greatly influences learners in different developmental aspects; as a result, learners should be provided with safe and stimulating environments that afford them with different developmentally appropriate materials, tasks and situations. This clearly shows that teachers should also create an environment that promotes independent learning, group exploration, play and interaction both with the teacher and among learners themselves.

\section{Play as a learning strategy}

Wood (2013) postulated that in ECE, play is considered essential for learning and development to take place. Wood (2013) argued that works of philosophers like Piaget have influenced ECE. For instance, Piaget identified three categories and stages of play (Piaget 1973). The first is practice play. This category of play caters for learners who are at the sensory motor stage. Learners at this stage enjoy exploring physical activities. The second, namely, symbolic and construction play, is normally enjoyed by learners at the preoperational stage. Learners at this stage enjoy, pretend, fantasise and enjoy socio-dramatic play that involves the use of mental representation. The third category of play is games with rules. This category caters for learners who are at the concrete operational stage. At this stage, learners enjoy a game with predetermined rules. I have also observed that at this stage, children make up the rules of a game as they go along.
The report of the Department of Education (2008) pointed out that the indigenous games that learners play in their communities possess different concepts of mathematics which learners enjoy enormously. Therefore, the report maintains that teachers should incorporate those games in their teaching. Ginsburg et al. (2008:7) contended that play 'provides valuable opportunities to explore and undertake activities that can be surprisingly sophisticated from a mathematical point of view'. For instance, while learners are playing with puzzles, they learn patterns, shapes and symmetries. However, Ginsburg et al. (2008) highlighted that play alone is not enough to explicitly teach mathematics to learners; as a result, teachers' support is still needed during play in order to assist learners to connect their play experiences with the formal learning of mathematics.

\section{Valuable moments to teach mathematics}

Ginsburg et al. (2008) asserted that there are teachable moments that teachers should be intelligent enough to identify. These moments allow and accept the presence of the teacher during free play to guide and unconsciously facilitate learning to take place. Teachers are expected to carefully observe learners as they play in order to identify activities and moments that promote the learning of mathematical concepts. If those moments are addressed opportunely, learners will have opportunities to experience excellent learning (Ginsburg et al. 2008). Teachers should therefore not focus only on managing the behaviours of learners but also pay more attention to and be knowledgeable about identifying moments to teach mathematical concepts during play.

Daily activities in schools have mathematical features that can be emphasised to create opportunities for the exploration of and conversation about key mathematical ideas, or the application of mathematical ideas in new contexts (Greenes et al. 2004). For instance, during sand or water play, teachers may enrich the play by providing a variety of containers. As learners play, the teacher utilises educational moments to teach concepts such as mass, volume and capacity. Instructing or asking questions such as 'Bring an empty container' or 'Which container is half full?' and 'Which one holds more water?' is effective in instilling mathematical concepts. Klibanoff et al. (2006:61) suggested that 'teachers should incorporate math talk naturally into their daily routines and create opportunities within the classroom that engage learners into conversations that include mathematical concepts'. This is because practices like these enhance the growth of learners in acquiring mathematical knowledge (Klibanoff et al. 2006).

\section{Projects that assist learners to learn}

There is a need for teachers to involve learners in projects that require them to learn and experience mathematical concepts in a practical manner. For instance, learners can be involved in a project of making their own table. This project will expose them to measurement, counting, height and 
space. Teachers need to assist learners to make sense of reallife problems through the use of projects, as this will add fun and stimulate learners to learn mathematics in a relaxed manner (Ginsburg et al. 2008). Effective mathematics instruction requires teachers to possess sound content knowledge and PCK (Shulman 1987). It is crucial for teachers to be competent in interpreting learners' thinking and integrating their actual teaching with learners' experiences, interests and needs.

\section{Intentional teaching of mathematics}

Notari-Syverson and Sadler (2008) argued that early childhood learners need to be prepared for more formal mathematics instruction in the later grades. Hence, they should be exposed to deep and explicit knowledge of high-quality mathematics education at preschool level. Mitchell et al. 1999 and $\mathrm{Ng}$ and Nirmala 2008 stated that the quality of instruction is determined by the engagement of the learner; therefore, instruction should help learners to connect their informal knowledge of mathematics with their experiences of formal mathematics. This connection can be done through manipulation of physical objects. However, teachers need to be clever enough to use them well because, if they do not, learners will fail to connect their use with new knowledge.

The ECE guidelines for teacher preparation, developed by NAEYC (2003), emphasised that teachers need to recognise the concepts and skills that are developmentally appropriate for young learners. More importantly, they must know what is essential in each content area and they also have to determine why these content areas are crucial. They should employ good strategies to simplify crucial parts of the content in order for learners to comprehend them easily. Teachers' knowledge of learners' developmental levels is very important because the teacher will recognise the impact of cognitive, language, social and emotional development on learners' understanding of topics presented to them (NAEYC 2003). Mitchell et al. (1999) insisted that teachers should demonstrate proficiency when teaching mathematics by possessing conceptual understanding. This means that they should understand the core knowledge of mathematics, the students and instructional practices needed for teaching. They should demonstrate an understanding of procedural fluency by carrying out basic instructional routines such as introducing the lesson and engaging learners in class activities. Teachers could as well demonstrate proficiency by being strategic when planning effective instruction and solving problems that arise while teaching. It is stated in the theoretical framework that teachers' knowledge of teaching strategies is important in the teaching process; therefore, the 'Theoretical framework' section discusses different strategies for teaching mathematics in Grade R.

\section{Theoretical framework}

The theoretical framework for this article was drawn from the work of Shulman (1987). Shulman stipulated seven domains of professional knowledge required for effective teaching, namely, subject matter content knowledge, PCK, curricular knowledge, general pedagogical knowledge, knowledge of learners, knowledge of educational contexts and knowledge of educational aims, goals and purposes (Table 1). Therefore, Shulman's knowledge domains were used to explore teachers' understanding of teaching and learning of mathematics in Grade R. Shulman (1987) argued that teaching is crucial because it develops the cognitive, physical and emotional skills of learners; therefore, it is

TABLE 1: Domains of professional knowledge for in-service teachers' understanding of the teaching of mathematics.

\begin{tabular}{|c|c|c|}
\hline Domains of professional knowledge & Interview questions & Observed classroom behaviours \\
\hline $\begin{array}{l}\text { Subject matter content knowledge } \\
\text { Curriculum knowledge }\end{array}$ & $\begin{array}{l}\text { What do you understand by the effective teaching of mathematics in } \\
\text { Grade R? } \\
\text { - Mention major content areas of mathematics that are stipulated in the } \\
\text { Grade R curriculum and give examples of mathematical concepts/topics } \\
\text { under each area. } \\
\text { - What do you understand are the differences between a triangle, square } \\
\text { and rectangle? }\end{array}$ & $\begin{array}{l}\text { - Organisation, logic and sequencing of the presentation of } \\
\text { mathematical concepts. }\end{array}$ \\
\hline Pedagogical content knowledge (PCK) & $\begin{array}{l}\text { - In your own understanding, which teaching strategies do you consider } \\
\text { effective when teaching mathematics to Grade R learners? Why? } \\
\text { - Do you think it is necessary to assess learners while teaching } \\
\text { mathematics and why? } \\
\text { - Which assessment methods do you consider are good to be used in } \\
\text { assessing learners? }\end{array}$ & $\begin{array}{l}\text { - Effective use of different teaching methods/strategies to } \\
\text { teach and assess mathematics. }\end{array}$ \\
\hline General pedagogical knowledge & $\begin{array}{l}\text { - In your own understanding, how do you think a Grade R classroom } \\
\text { for the teaching of mathematics should be arranged and organised? } \\
\text { - How do you understand the planning of the lesson plan/lesson activities } \\
\text { for mathematics should be like? }\end{array}$ & $\begin{array}{l}\text { - Classroom arrangement and organisation. } \\
\text { - Integration of mathematical concepts with other subjects. }\end{array}$ \\
\hline Knowledge of learners & $\begin{array}{l}\text { - In your own understanding, how do you think learners in Grade R learn } \\
\text { mathematics? Explain. } \\
\text { - In your own understanding, what do you understand by the fact that } \\
\text { learners are different? }\end{array}$ & $\begin{array}{l}\text { - Learners' engagement in doing classroom activities. } \\
\text { - Classroom activities cater for different learning styles and } \\
\text { cognitive development. } \\
\text { - Reviewing prior knowledge of learners before teaching new } \\
\text { knowledge. }\end{array}$ \\
\hline $\begin{array}{l}\text { Knowledge of educational contexts. } \\
\text { Knowledge of educational aims, goals } \\
\text { and purposes }\end{array}$ & $\begin{array}{l}\text { - In your own understanding, do you think mathematics offered in Grade } \\
\mathrm{R} \text { is applicable in the daily life activities of learners? }\end{array}$ & $\begin{array}{l}\text { - Use of concrete locally available materials. } \\
\text { - Contextualisation of games, songs and examples used. } \\
\text { ungaging learners in activities that help them to have deep } \\
\text { questions. }\end{array}$ \\
\hline
\end{tabular}


imperative to know what is in teachers' minds and how they carry out their duties. Morrow 2007 and Pugh and Duffy 2013 agree with Shulman, clarified that the fundamental duty of a teacher is to teach a child based on knowledge of what to teach and how to teach it. The seven knowledge bases that Shulman (1987) identified are regarded as the minimum knowledge required for teaching; these were used in this article to generate and analyse data regarding in-service teachers' understanding of the teaching of mathematics in Grade R. The seven knowledge bases are as follows: content knowledge; general pedagogical knowledge; curriculum knowledge; PCK; knowledge of learners and their characteristics; knowledge of educational contexts; and knowledge of educational purposes and values as well as of philosophical and historical influences.

Shulman (1987) indicated that teachers must possess and demonstrate subject matter content knowledge. This means that they should know the facts, concepts, organisation, principles and structures of the subject they teach. Shulman argues that the teacher must show an understanding in terms of why a particular topic is essential to a discipline while another may be somewhat minor. He asserted that teachers must be knowledgeable and have an understanding of the subject matter themselves. They should demonstrate competences regarding the use of rules and laws that govern the subject matter. Shulman (1987:9) further pointed out that 'content knowledge requires going beyond knowledge of the facts or concepts of a domain; instead, it requires understanding the structures of the subject matter'. Ball, Thames and Phelps (2008) agreed with Shulman (1987) that teachers themselves should know the subject matter in order to be able to help learners to learn the content.

Shulman (1987) referred to PCK as the representation and formulation of subject matter in such a way that it is understandable to others. Shulman pointed out that to enable learners to understand the subject matter, teaching strategies, such as analogies, illustrations, discussions, examples and explanations, can be used to present the content and ideas in a lesson. Hurrell (2013:55) added that teachers' ability to employ those strategies requires 'a practical knowledge of teaching and learning guided through a contextualised knowledge of a particular classroom setting'.

Curricular knowledge is another domain which Shulman describes as a requirement for teachers' knowledge. This means that they need to know and understand the subject content, the topics and programmes as stipulated in the curriculum of the subject they teach. Moreover, they need to know and understand the variety of instructional materials available for the programme. Chukwubikem (2014) insisted that those resources provided by the curriculum should be informative and practical, and must suit a range of early childhood settings. The curriculum should provide examples of how teachers can create a stimulating environment for their learners in order to make use of the most critical period of rapid development in learning. Seo and Ginsburg 2004 and Marbina Church and Tayler 2011 also suggested that teachers should be able to implement the Grade $R$ mathematics curriculum in an effective and developmentally appropriate manner. It is therefore important for teachers to understand all the topics in the curriculum; that is, its depth, breadth and sequence. Understanding of the topic should enable teachers to connect their knowledge of the subject with the topics they are to teach in Grade $\mathrm{R}$ in a harmonious manner. This underscores the need for teachers to work towards teaching all the stipulated topics in the curriculum and be creative in altering the curriculum if the need arises.

Shulman (1987) defined general pedagogical knowledge as teachers' knowledge and understanding of broad principles and strategies of classroom management and organisation that apply to the subject to be taught. The NAEYC and the NCTM (2002) suggested that within the classroom, teachers should enrich learners' natural interest in mathematics as well as create a favourable classroom environment that helps learners to develop traits like curiosity, imagination, persistence and flexibility. Teachers are therefore expected to arrange the classroom in a manner that will display different learning and discussion areas. There has to be a display of learners' work regarding mathematics and posters that spontaneously enhance learning of mathematics.

\section{How data were analysed}

Relevant documents were reviewed to supplement the data obtained from the interviews and observations in order to triangulate the findings. Training offered to teachers should equip them with adequate knowledge and skills that will enable them to blend together content knowledge, knowledge of learners, and contextual and general pedagogical knowledge (NAEYC \& NCTM 2002; Mathematics Learning Study Committee 2001; Shulman 1987). The five teachers who participated in this study were completing their training, Lesotho Certificate of Education, of which the mathematics/ numeracy course was one amongst many courses that they had to study. The components that were focussed on in this study were topic areas of a subject, instructional goals and expected outcomes that aligned with course polices, curricular design and methods of evaluation and assessment. The findings reveal that the mode of the course outline used during the training of these teachers possibly impacted their teaching of mathematics negatively because the course did not cover all the major content areas of mathematics. The course also did not cater adequately for subject content knowledge, as posited by Shulman (1987). This course seemed to cater for PCK (Shulman 1987) only because it dwelled extensively on how to teach selected mathematical concepts that appeared within the three areas of mathematics. In my view, information on content knowledge suffered a lot; as a consequence, the teachers' PCK was affected negatively, as demonstrated by their lack of understanding of the mathematical concepts that they were to teach in Grade R.

An analysis of the curriculum document revealed that its structure lacked important aspects that need to be contained in a curriculum such as sequence, scope and depth of content. 
It also failed to stipulate any long- and short-term goals and objectives as required in a curriculum document. It was therefore possible that teachers lacked adequate knowledge of the teaching of mathematics in Grade $\mathrm{R}$ as the curriculum document that they used was inadequate. Moreover, even though teachers were able to mention reflective reasons that portrayed possible long-term goals and objectives for teaching mathematics in Grade R, the curriculum document itself did not stipulate those objectives; as a consequence, teachers were denied an opportunity to possess knowledge of educational aims, goals and purposes in terms of the long- and short-term goals of education and also of the subject, as should be spelt out by government authorities (Shulman 1987).

The findings from analysis of the documents that was used were also presented and discussed. The lesson plans presented by all five teachers were compared and summarised in a table. The documents that were analysed were the Grade $\mathrm{R}$ curriculum for mathematics, the Course Outline of a mathematics/numeracy Course and teachers' lesson plan.

\section{Ethical consideration}

Ethical clearance was obtained from the Research Office at the University of KwaZulu-Natal (HSS/0438/014M).

\section{The findings of this research}

The findings of this article indicated that teachers possessed limited knowledge and understanding of the professional domains of knowledge (Shulman 1987) that each teacher should possess in order to teach effectively in any applicable discipline. The authors therefore recommend that the training of mathematics teachers should offer a module that will introduce them to different educational theories that disclose how young learners learn mathematics. Teacher trainees should also be exposed to a module that will facilitate the acquisition of subject matter knowledge of mathematics.

The findings further revealed that in-service teachers experienced challenges to teaching mathematics effectively because they lacked knowledge of the domains of professional knowledge as advocated by Shulman (1987), such as subject matter content knowledge, PCK, curriculum knowledge and knowledge of the learners. The lack of such knowledge negatively impacted their planning and actual teaching of mathematics in Grade R. However, most of the research respondents had difficulties mentioning the three major content areas of mathematics that are stipulated in the curriculum, and they were unable to provide an example of one mathematical concept under each main idea.

'This was revealed by one of the responses that: They are number, measurement, sorting, and counting. Err ... [pause] under number the concepts are counting, err ... Classifying. I can't recall others.' (Participant 1, Pre-service teacher)

'I think they are sorting, matching, comparing, measuring and classifying. Ache! I remember eee .... Counting. Ache! I am not sure madam.' (Participant 2, Pre-service teacher)
'Eee ...! Sorting, classifying, measuring, shapes, eer ...! I have forgotten other areas, but I know they are written in the curriculum. Ok I remember, counting and one-to-one correspondence, I think those are the ones that I can recall now.' (Participant 1, Pre-service teacher)

From the above responses, it was clear that there were confusions in the major content areas of mathematics with mathematical concepts that appear under the main content areas of mathematics. It shows that some teachers did not know - or they had a limited understanding of - the requirements of the curriculum in spite of the fact that they claimed to be teaching curriculum content.

\section{Recommendations}

The research recommended that the training of mathematics teachers should offer a module that will introduce the Grade $R$ teachers to different educational theories that disclose how young learners learn mathematics. Teacher trainees should also be exposed to a module that will facilitate the acquisition of subject matter knowledge of mathematics. It was evident that teachers were not familiar with the Grade R curriculum for mathematics document as they all responded during the interviews that effective teaching meant to teach the contents of the curriculum; however, they experienced difficulties in referring to the contents of the curriculum. This showed that the teachers were not planning their teaching with reference to the curriculum. Recommendations were that the MoET prepare as a matter of urgency a Grade R curriculum document for mathematics based on sound research using, for example, NCTM (2013) guidelines. The new curriculum should include all five major content areas of mathematics and all the necessary information such as the scope, sequence and depth of the topics to be taught as well as activities that guide teachers to design relevant and interesting lesson plans for mathematics. A content analysis plan was used, and data were first summarised and then categorised, after which themes were assigned to those categories. Data were obtained from preservice teachers. Curriculum for mathematics document revealed that the curriculum lacked many elements that need to be addressed, because important omissions from such a document affect teachers' understanding of what is to be taught in Grade R. The data and a discussion of the findings from five classroom observations followed the presentation of the interviews. In this section, data from the classroom observation process were presented and each observation was followed by reflection and discussion. The findings from an analysis of the documents that the authors perused were also presented and discussed. The lesson plans that were presented by all five preservice teachers were compared and summarised in a table.

\section{Conclusion}

This article explored teachers' understanding of the teaching of mathematics in Grade R. A comprehensive literature review provided a theoretical framework within which this article was located. This article mainly focussed on three case paper schools in Lesotho, where teachers were interviewed and 
observed during teaching mathematics to Grade R learners. This article concluded that teachers experienced challenges to teaching mathematics effectively because they lacked knowledge of the domains of professional knowledge as advocated by Shulman (1987), such as subject matter content knowledge, PCK, curriculum knowledge and knowledge of the learners. The lack of such knowledge negatively impacted their planning and actual teaching of mathematics in Grade R.

\section{Acknowledgements}

The authors are grateful for the participation of Grade $\mathrm{R}$ in-service teachers from Lesotho during this study.

\section{Competing interests}

The authors declare no conflict of interests.

\section{Authors' contributions}

Both authors contributed equally to this work.

\section{Funding information}

Funding for this study was received from the Kellogg's students' funding.

\section{Data availability statement}

There were no new data created or analysed in this study.

\section{Disclaimer}

The views and opinions expressed in this article are those of the supervisor and the students, and they do not necessarily reflect the official policy.

\section{References}

Aubrey, C., 1997, 'Children's early learning of number in school and out', in I. Thompson (ed.), Teaching and learning early number, pp. 20-29, Open University Press, Philadelphia, PA.

Ball, D.L., Thames, M.H. \& Phelps, G., 2008, 'Content knowledge for teaching: What makes it special?', Journal of Teacher Education 59(5), 389-407. https://doi. org/10.1177/0022487108324554

Barnett, C. \& Tyson, P., 1999, 'Case methods and teacher change: Shifting authority to build autonomy', in M. Lundeberg, B. Levin \& H. Harrington (eds.), Who learns what from cases and how?, Lawrence Erlbaum Associates, Mahwah, NJ.

Benner, S.M. \& Hatch, J.M., 2009, 'From the editors: Math achievement and early childhood teacher preparation', Journal of Early Childhood Teacher Education 30(4), 307-309. https://doi.org/10.1080/10901020903320239

Borg, S., 2011, 'The impact of in-service teacher education on language teachers beliefs', System 39, 370-380.

Chukwubikem, I.E.P., 2014, 'International letters of social and humanistic sciences', Resources for Early Childhood Education, 8(1), 1-91.

Clement, L.L., 2001, 'What do students really know about functions?', The Mathematics Teacher 94(9), 745

Community Learner Care of Victoria, 2011, Early literacy and mathematics self-guided learning package: Resource and development unit, Sage, Los Angelos, CA.

De Lemos, M. \& Doig, B., 1999, Who am I? Developmental assessment manual, Australian Council for Educational Research, Melbourne.

Department of Education, 2008, Foundations for learning campaign 2008-2011 Department of Education No. 306, Government Gazette 30880, 14 March 2008, Department of Education, Pretoria.

Department of Education and Early Childhood Development, 2011, Victoria as learning community-extended special lecture, Melbourne Graduate School of Education, Melbourne.
Ginsburg, H.P. \& Amit, M., 2008, 'What is teaching Mathematics to young children? A theoretical perspective and case study', Journal of Applied Developmental Psychology 29(4), 274-285. https://doi.org/10.1016/j.appdev.2008.04.008

Ginsburg, H.P., Lee, J.S. \& Boyd, J.S., 2008, 'Mathematics education for young children: What it is and how to promote it. Social policy report', Society for Research in Child Development 22(1), 1-24. https://doi.org/10.1002/j.2379-3988.2008.tb00054.x

Greenes, C., Ginsburg, H.P. \& Balfanz, R., 2004, 'Big Maths for little kids', Early Childhood Research Quarterly 19(1), 156-166. https://doi.org/10.1016/j. ecresq.2004.01.010

Hurrell, D.P., 2013, 'What teachers need to know to teach Mathematics: An argument for a reconceptualised model', Australian Journal of Teacher Education 38(11), 21-78. https://doi.org/10.14221/ajte.2013v38n11.3

International Step by Step Association, 2010, Competent educators of the 21st century: Principles of quality pedagogy, International Step by Step Association, Leiden.

Jordan, N.C., Kaplan, D., Ramineni, C. \& Locuniak, M.N., 2009, 'Early math matters: Kindergarten number competence and later Mathematics outcomes', Developmental Psychology 45(3), 850. https://doi.org/10.1037/a0014939

Jung, M. \& Conderman, G., 2013, 'Intentional Mathematics teaching in early childhood classrooms', Childhood Education 89(3), 173-177. https://doi.org/10.1080/00094 056.2013.792689

Kiggundu, E., 2007, 'Teaching practice in the Greater Vaal triangle area: The student teachers' experience', Journal of College Teaching and Learning 4(6), 2536. https://doi.org/10.19030/tlc.v4i6.1572

Klibanoff, R.S., Levine, S.C., Huttenlocher, J., Vasilyeva, M. \& Hedges, L.V., 2006 'Preschool children's mathematical knowledge: The effect of teacher "math talk", Developmental Psychology 42(1), 59. https://doi.org/10.1037/0012-1649.42.1.59

Lampert, M. \& Ball, D.L., 1998, Teaching, multimedia and mathematics: Investigations of real practice, Teachers College, Columbia University, New York, NY.

Lesotho, 2005, Education sector strategic plan, 2005-2015, Ministry of Education and Training, Maseru.

Lesotho Ministry of Education and Training, 2012, Education Statistics Bulletin 2012, Moet, Maseru.

Marbina, L., Church, A. \& Tayler, C., 2011, Victorian early years learning and development framework evidence paper practice principle 6 integrated teaching and learning approaches, University of Melbourne, Melbourne, viewed 10 December 2015, from www.education.vic.gov.au/Documents/childhood/providers/edcare/eviintegteac.pdf.

Mathematics Learning Study Committee, 2001, Adding it up: Helping children to learn mathematics, National Academies Press, Washington, DC

McGuire, P., Kinzie, M.B. \& Berch, D.B., 2012, 'Developing number sense in pre-k with five-frames', Early Childhood Education Journal 40(4), 213-222. https://doi. org/10.1007/s10643-011-0479-4

Mitchell, C. \& Weber, S., 1999, Reinventing ourselves as teachers: Beyond nostalgia, Psychology Press.

Ministry of Education and Training, 2005, Education sector strategic plan 2005-2015, Paragon Business Products, Maseru.

Missall, K.N., Mercer, S.H., Martínez, R.S. \& Casebeer, D., 2012, 'Concurrent and longitudinal patterns and trends in performance on early numeracy curriculumbased measures in kindergarten through third grade', Assessment for Effective Intervention 37(2), 95-106. https://doi.org/10.1177/1534508411430322

Morrow, W., 2007, Learning to teach in South Africa, HSRC Press, Cape Town

Murray, J., Farrington, D.P. \& Sekol, I., 2012, 'Children's antisocial behavior, mental health, drug use, and educational performance after parental incarceration: A
systematic review and meta-analysis', Psychological Bulletin 138(2), 175. https:// systematic review and meta
doi.org/10.1037/a0026407

Nancy, L., 2007, 'Critical thinking dispositions as an outcome of undergraduate education', The Journal of General Education 56(1), 17-33. https://doi. org/10.1353/jge.2007.0011

National Association for the Education of Young Children and National Council for Teachers of Mathematics, 2002, Early childhood maths: Promoting good beginnings, viewed 02 June 2014, from http://www.naeyc.org/about/ positionspdf/psmath.pdf.

National Council for Teachers of Mathematics, 2013, Mathematics in early childhood learning: A position of the National Council of Teachers of Mathematics, viewed 10 May 2015, from www.nctm.org/earlychildhoodmath.

National Council for Teachers of Mathematics (NCTM), 2013, Mathematics in early childhood learning. A position of the National Council of Teachers of Mathematics, viewed 10 May 2018, from http://www.nctm.org/earlychildhoodmath.

National Research Council, 2002, Learning and understanding: Improving advanced study of Mathematics and science in U.S. high schools, in J. Gollub, M. Bertenthal, J. Labov \& P. Curtis (eds.), National Academy Press, Washington, DC.

Ng, S.S.N. \& Nirmala, R., 2008, 'Mathematics teaching during the early years in Hong Kong: A reflection of constructivism with Chinese characteristics', Early Years 28(2), 159-172. https://doi.org/10.1080/09575140802020917

Notari-Syverson, A. \& Sadler, F.H., 2008, 'Math is for everyone: Strategies for supporting early mathematical competencies', Young Exceptional Children 11(3), 145-156.

Piaget, J., 1973, Piaget in the classroom, Routledge and Kegan Paul Publishers, London. Pugh, G. \& Duffy, B., 2013, Contemporary issues in the early years, Sage, Los Angelos, CA. Schifter, D., 1996, 'A constructivist perspectives on teaching and learning mathematics', in C.T. Fosnot (ed.), Constructivism theory and practice, pp. 73-91, Teachers College Press, New York, NY. 
Seo, K.-H. \& Ginsburg, H.P., 2004, 'What is developmentally appropriate in early childhood mathematics education? Lessons from new research', in D.H. Clements, J. childhood mathematics education? Lessons from newresearch, in D.H. Clements, for early childhood mathematics education, pp. 91-104, Erlbaum, Hillsdale, NJ.

Shulman, L.S., 1987, 'Knowledge and teaching: Foundations of new reform', Harvard Educational Review, 57(1), 1-21. https://doi.org/10.17763/haer.57.1.j463w79r 56455411

Stigler, J.W. \& Hiebert, J., 1999, The teaching gap: Best ideas from the world's teachers for improving education in the classroom, The Free Press, New York, NY.

UNICEF, 1994, The state of the world's children 1998, UNICEF, New York, NY.

Van de Rijt, B., Van Luit J. \& Pennings, A., 1999, 'The construction of the Utrecht Early Mathematical Competence Scales', Educational and Psychological Measurement 59, 289-309. https://doi.org/10.1177/0013164499592006
Varol, F. \& Farran, D.C., 2006, 'Early mathematical growth: How to support young children's mathematical development', Early Childhood Education Journal 33(6), 381-387. https://doi.org/10.1007/s10643-006-0060-8

Walia, P., 2012, 'A comparative study of constructivist approach and traditional approach on achievement in mathematics', Educational Quest-An International Journal of Education and Applied Social Sciences 3(2), 171-175.

Williams, K., 2008, Report confirms Foundation Phase fiasco, Government Gazette, National Policy for Integrated Early Childhood Care and Development 2013, Department of Education, viewed 01 July 2013, from http://kirstywilliams.org.uk/ news/00470/reportconfirmsfoundationphasefiasco.

Wood, E., 2013, Play, learning and early childhood curriculum, 3rd edn., Sage, Los Angeles, CA. 